\title{
DESENTRALISASI, BASIS SOSIAL DAN PRAKTEK KEKUASAAN ELIT POLITIK DI TINGKAT LOKAL PASCA PENERAPAN OTONOMI DAERAH
}

\author{
Yustinus Suhardi Ruman \\ Jurusan Psikologi, Fakultas Psikologi, Bina Nusantara University \\ Jln. K.H. Syahdan No. 9, Kemanggisan, Palmerah, Jakarta Barat 11480
}

\begin{abstract}
Decentralization basically is acknowledged would make development process at the local level runs democratic. Otherwise, democracy at the local level is not only determined by the existing of democracy institution at the local level (election, parties, non-governmental organization). Democracy at the local level is also determined by behaviour and power practices by local elites at the local level. This journal shows that power practices at the local level tend to corrupt, ollygarchy and full of intimidations. Political elites who participate in the local political contestation tend to have social basic from the new order and the local nobles.
\end{abstract}

Keywords: decentralization, social basic, elite power, politic, autonomy

\begin{abstract}
ABSTRAK
Desentralisasi pada dasarnya diakui akan membuat proses pembangunan pada tingkat lokal akan berjalan secara demokratis. Namun demokrasi pada tingkat lokal tidak hanya ditentukan oleh ada atau tidak adanya institusi demokrasi pada tingkat lokal. Demokrasi pada tingkat lokal, juga ditentukan oleh perilaku dan praktek kekuasaan yang dilakukan oleh para elit politik di tingkat lokal. Tulisan ini menunjukan bahwa praktek kekuasaan pada tingkat lokal justru cenderung koruptif, oligarkis dan penuh dengan kekerasan. Elit politik yang hadir dalam kontestasi politik lokal cendrung memiliki basis sosial pada orde baru dan para bangsawan.
\end{abstract}

Kata kunci: desentralisasi, basis sosial, kekuasaan elit, politik, otonomi 


\section{PENDAHULUAN}

Reformasi politik tahun 1998 tidak hanya berhasil menurunkan Soeharto dari tampuk kekuasaan yang jalanianya selama 30 tahun, tetapi juga membawa perubahan dalam sistem pemerintahan. Sebagaimana yang telah diketahui umum bahwa pemerintahan Orde Baru menerapkan sistem pemerintahan yang sentralistik. Jakarta menjadi pusat pembuatan kebijakan politik apapun termasuk dibidang pembangun. Posisi Pemerintah Daerah dalam konteks ini hanya merupakan perpanjangan tangan pemerintah pusat. Dan pembangunan yang dilaksanakan di daerah baik dalam bidang politik, sosial, budaya dan ekonomi ditujukan untuk memperkuat visi sentralisme. Dalam kaitan dengan ini, pembangunan tidak ada hubunganya dengan peningkatan partisipasi dan distribusi sumber daya baik sumber daya politik maupun ekonomi.

Namun semangat reformasi telah melahirkan beberapa perubahan mendasar dalam bidang sistem politik dan administrasi pemerintahan. Beberapa perubahan mendasar itu adalah sistem otonomi daerah, sistem pemilu dengan multi partai dan adanya pemilihan umum langsung. Perubahan ini memberikan dampak yang luar biasa bagi tingginya partisipasi dan semakin terbukanya kesempatan masyarakat lokal untuk berpartisipasi baik dalam kehidupan politik, sosial maupun ekonomi. Masyarakat tiba-tiba dihadapkan pada berbagai macam kesempatan di mana mereka dapat memilih untuk berpartisipasi mewujudkan mimpi-mimpi mereka. Peluang untuk menjadi elit politik bukan lagi suatu kesempatan yang langka dan sulit. Peluang-peluang itu nyata dan sungguh hadir di hadapan wajah mereka.

Desentralisasi juga dapat dimaknai sebagai terbukanya kesempatan besar untuk menjadi Pegawai Negeri Sipil yang tidak saja memberikan jaminan pekerjaan untuk jangka yang panjang, tetapi juga sebuah status yang memainkan peranan sosial penting pada konteks masyarkat lokal. Singkatnya desentralisasi menghidupkan kembali harapan yang telah lama dalam pemerinthan Orde Baru terus meredup.

Secara politik sistem desentralisasi sebagaimana yang dikemukakan oleh Nordholt \& Klinken (2007) sebetulnya adalah untuk mengakomodasi sentimen-sentimen anti-jakarta di banyak daerah di luar Jawa. Pada saat itu, seperti yang dicatat oleh Nordholt \& Klinken (2007), Partai Golkar masih berkuasa dan mereka memiliki basis-basis yang kuat di luar Pulau Jawa. Ketidakpastian mengenai masa depan, memaksa Partai Golkar berusaha melancarkan gerakan-gerakan untuk desentralisasi. Dengan cara ini, Partai Golkar berusaha mempertahankan basis-basisnya di luar Jawa.

Analisa Nordholt \& Klinken di atas memberi kesan bahwa desentralisasi merupakan sebuah kebijakan yang bersifat pragmatis dari sisi politis. Namun, pragmatisme politik tersebut telah diterima dengan penuh keyakinan akan masa depan oleh masyarakat pada tingkat lokal. Tidak mengherankan setelah terbitnya Undang-Undang no 23 dan 25 tahun 1999 mengenai Pemerintah Daerah dan Keungan Pemerintah Daerah gerakan-gerakan pemekaran untuk menjadi daerah otonom tumbuh bagai jamur di musim hujan. Tulisan ini akan membahas pertannyaan apakah desentralisasi sama dengan demokratisasi pada tingkat lokal.

\section{METODOLOGI PENELITIAN}

Tulisan ini tidak didasari pada penelitian lapangan, melainkan di dsarakan pada analisa dan hasil penelitian terhadulu yang dilakukan oleh para peneliti lain yang berminat pada masalah-masalah demokrasi pada tingkat lokal pasca penerapan otonomi daerah. Sebetulnya, ada dua pendekatan yang digunakan oleh para peneliti untuk menganalisa masalah demokrasi pada tingkat lokal yaitu 
pendekatan institusioanl dan pendekatan perilaku (behaviorisme) para elit. Pendekatan institusional akan berfokus pada ada atau tidak adanya insitusi-institusi demokrasi pada tingkat lokal dan bagaimana institusi-institusi tersebut menjalankan perannya secara fungsional. Sedangkan pendekatan perilaku para elit memberi perhatian pada basis sosial dari elit dan bagaimana elit menjalankan kekuasaan.

Dalam tulisan ini, penulis akan mengeksplorasi penelitian-penelitan dan analisa-analisa yang berkaitan dengan basis sosial dan perilaku para elit pada tingkat lokal dalam menjalankan kekuasaan yang mereka miliki. Dan oleh karena itu tulisan ini memilih pendekatan perilaku elit. Masalah yang akan dibahas dalam tulisan ini adalah basis sosial dari para elit politik dan bagaimana para elit menjalankan kekuasaannya pada tingkat lokal. Sebelum membahas basis sosial dan perilaku kekuasaan para elit, tulisan ini akan didahului dengan sebuah deskripsi singkat mengenai desentralisasi.

\section{HASIL DAN PEMBAHASAN}

\section{Desentralisasi}

Literatur-literatur ilmu politik dan ilmu-ilmu sosial lainnya secara teoretis menempatkan Otonomi Daerah di bawah tema desentralisasi. Desentralisasi (Braun \& Grote, 2000) pada umumnya didefenisikan sebagai transfer otoritas dan tanggung jawab fungsi-fungsi publik dari suatu pemerintah pusat kepada sub-pemerintah di bawahnya. Desentralisasi meliputi perbedaan kekuasaan pembuatan keputusan dan tanggung jawab kepada sub-unit pemerintahan. Dalam kaitannya dengan demokrasi desentralisasi diprediksi akan membawa suatu keuntungan demokratis di mana dalam setiap pembuatan dan implementasi kebijakan publik partisipasi masyarakat menjadi lebih kondusif.

Pertanyaannya sekarang adalah bahwa kondisi seperti apakah desentralisasi dapat mencerminkan demokrasi dan apa manfaat dari desentralisasi itu sendiri? Ribot (2007) menyebut tiga kondisi desentralisasi yang dapat mencerminkan demokrasi pada tingkat lokal. Pertama adalah representasi. Partisipasi yang demokratis warga masyarakat secara institusional dapat dilakukan melalui perwakilan mereka di lembaga perwakilan. Proses ini biasanya didahului dengan pemilihan umum. Namun Ribot menegaskan bahwa model representasi ini mengandaikan bahwa para pemimpin bersikap responsif dan akuntabel terhadap masyarakat. Kondisi yang kedua adalah citizenship. Ribot mengemukakan bahwa citizenship dapat dibangun berdasarkan kepentingan yang sama seperti kelompok-kelompok privat dan NGO, atau juga berdasarkan identitas kultural. Singkatnya citizenship bersifat multikultural. Dalam konteks ini, pengakuan akan eksistensi citizenship menjadi suatu yang fundamental dalam desentralisasi. Dan kondisi yang ketiga adalah public domain. Domain publik merupakan suatu ruang dimana citizen merasa dapat dan ditopang untuk mempengaruhi, mempertahankan dan memperkuat kepemilikan dan identitas publik. Ribot menegaskan bahwa domanin publik harus menjadi bagian dari representasi dan produksi citizenship. Domain publik dengan demikian merupakan suatu ruang tindakan kolektif integratif. Domain publik merupakan sesuatu yang essensial bagi desentralisasi yang berhasil.

Menjawab pertannyaan di atas Katorobo (2004) mengemukakan bahwa desentralisasi akan mencerminkan demokrasi bila pemerintah daerah (legislatif maupun eksekutif) memiliki komitmen politik yang kuat untuk mengimplementasikan program-program desentralisasi, mempromosikan keterlibatan kelompok akar rumput dalam pembuatan keputusan, adanya kerangka kerja legislatif yang kondusif dan dukungan konstitusional bagi desentralisasi. 
Sedangkan berkaitan dengan manfaat desentralisasi Darmawan (2008) menulis bahwa salah satu keuntungan dengan adanya desentralisasi adalah adanya partisipasi yang luas dari warga masyarakat. Partisipasi warga ini memiki dua dimensi yakni sebagai prakondisi dan sebagai tujuan yang harus dicapai melalui desentralisasi. Lebih lanjut ia mengemukakan bahwa desentralisasi memberi kesempatan kepada pemerintah untuk dapat mengaksesi preferensi warga dan untuk mengidentifikasi kondisi-kondisi lokal sehingga aktivitas mereka dapat memenuhi kebutuhan lokal dan dengan demikian menciptakan insentif kepada politisi lokal untuk menjadi lebih akuntabel terhadap konsituen mereka. Keuntungan lain dengan desentralisasi adalah semakin meningkatnya kontrol warga masyarakat terhadap setiap kebijakan pembangunan.

Dalam artikel yang berjudul Decentralization of Governance and Development, Bardhan (2002) menulis bahwa desentralisasi telah dihargai sebagai kerangka institusi utama bagi pertumbuhan industri yang fenomenal di China selama dua dekade terakhir. Sementara itu Van Berkel (2006) menegaskan bahwa desentralisasi memungkinkan setiap kebijakan program pembangunan untuk beradaptasi dengan kebutuhan-kebutuhan dan kondisi-kondisi lokal. Berkel juga mengemukakan bahwa pertama desentralisasi akan membuat setiap kebijakan sosial menjadi lebih fleksibel dan lebih efektif. Kedua, desentralisasi juga akan dapat merangsang bertubuhnya bentuk-bentuk partnership lokal yang sesuai dengan masalah-masalah sosial yang muncul pada tingkat lokal. Dan ketiga, desentralisasi memiliki potensi inklusivitas karena mempromosikan keterlibatan aktor-aktor lokal (citizens, social partner, local public insitutuions) dalam proses pembuatan dan delivery kebijakan.

Seperti pendapat-pendapat sebelumnya Peterson (dalam Aspinal \& Fealy, 2003) dalam tulisannya mengenai Amerika Latin, juga mengemukakan bahwa desentralisasi dapat memperkuat partisipasi demokrasi dalam pemerintahan dan meningkatkan kualitas terhadap pelayanan publik.

\section{Basis Sosial Para Elit Politik Lokal}

Anaslisa mengenai basis sosial para elit politik lokal sangat penting. Penting karena dengan menganalisa basis sosial para elit politik, para peneliti akan dapat menjelaskan sejauh mana proses transisi demokrasi terjadi pada tingkat lokal. Deskripsi berikut ini berasal dari beberapa riset yang menunjukan basis sosial dari para elit politik lokal pasca penerapan otonomi daerah.

Hadiz (2010) dalam studinya mengenai basis sosial dan politik para elit di Sumatera pada pasca tumbangnya Orde Baru mengemukakan bahwa Elit-elit Orde Baru sebelumnya telah belajar untuk mendominasi demokrasi pada level lokal melalui penggunaan politik uang dan berbagai macam intimidasi dan mobilisasi politik. Sampai sejauh ini kaum reformis yang terpercaya juga telah menjadi bagian dari politik uang. Di antara elit-elit Orde Baru ini adalah birokrat-birokrat tua yang sekarang ingin mentransformasikan kedudukan mereka yang panjang dalam birokrasi ke dalam kepemilikan kekuasaan secara langsung, mereka melihat hal ini dengan bergabung dengan koalisi lokal. Di antara elit-elit politik terdapat enterpreneuer lokal yang juga memiliki ambisi yang sama. Mereka ini memperkuat posisi ekonomi mereka melalui kepemilikan kekuasaan politik langsung. Secara historis banyak dari antara mereka ini memiliki hubungan yang panjang sebelumnya dengan Golkar.

Para elit-elit lokal ini melihat desentralisasi sebagai suatu kesempatan untuk menekan klaim mereka untuk tempat-tempat yang istimewa dalam sistem post autoritarian. Mereka terlibat dengan jargon untuk melindungi agama, budaya dan identitas lokal. Dalam konteks ini tidak mengherankan kalau ada yang beranggapan bahwa hanya orang kaya yang akan memenangi politik.

Dalam era desentralisasi ini, kompetisi antara elit lokal tidak diatur dengan baik sebagai mana yang tejadi pada Orde Baru. Hal ini menimbulkan konflik kepentingan antara para aktor tidak dapat dihindari. Selain itu mengutip Obidzinski, Hadiz (2010) juga mencatat bahwa pada era desentralisasi ini posisi bupati sangat kuat terumasuk untuk mengontrol bisnis. Para elit politik lokal pada umumnya 
merupakan aktor-aktor yang menjadi bagian dari kekuasaan Orde Baru. Hadiz juga menjelaskan bagaimana proses dan mekanisme para elit lokal mempertahankan posisi mereka pasca autoritarian. Para elit politik ini uang dan kekerasan merupakan mekanisme yang digunakan untuk mempertahankan posisi mereka seperti yang dilakukan oleh Orde Baru untuk mempertahankan stabilitas, para politisi lokal juga intimidasi dan penyebaran ketakutan.

Selain Orde Baru sebagai basis sosial dari para elit politik lokal, sebagaimana yang ditunjukan oleh Jacqueline Vel (dalam Nordholt \& Klinken, 20078) berikut ini, basis sosial para elit politik lokal pasa perapan otonomi daerah adalah para bangsawan lokal. Vel mencatat dalam kasus Pemekaran Sumba Barat bahwa hukum-hukum dan insitusi-institusi baru yang diciptakan ditingkat nasional dianggap sebagai kesempatan oleh para anggota elit lokal. Para elit ini adalah para bangsawan lokal. Para bangsawan ini memiliki status yang secara tradisional dianggap memadai untuk diterima sebagai pemimpin yang posisinya dalam pemerintahan atau sektor swasta pada masa Orde Baru tidak memuaskan mereka atau juga posisinya menempatkan mereka di luar lingkungan para pembuat keputusan.

\section{Praktek Kekuasaan}

Eindhove (dalam Nordholt \& Klinken, 2007) mengenai praktek kekuasaan di Mentawai mengemukakan bahwa di satu sisi pihak elit politik lokal sibuk dengan mendirikan perusahaanperusahaan kontraktor, melakukan praktek-praktek kolutif dalam peneriamaan PNS, melakukan politik diskriminasi terhadap etnis-etnis minoritas dan pendatang, dan pada pihak yang lain orangorang biasa hanya menjadi penonton, diberitahu ketika keputusan-keputusa besar sudah dibuat. LSMLSM lokal juga cenderung memainkan peran mendua dalam keseluruhan proses kebijakan yang dibuat dengan bottom-up. LSM-LSM mengubah diri menjadi kubu-kubu politis.

Erman (dalam Nordholt \& Klinken, 2007) dalam studinya mengenai praktek desentralisasi di Bangka mengemukakan bahwa aktor negara tingkat lokal sering terlibat dalam mafia bisnis. Di satu pihak para birokrat di satu sisi mempunyai akses kekuasaan untuk memberikan izin, memberikan proteksi, membuat dan mengesahkan peraturan, namun pada sisi yang lain tidak mempunyai dana yang cukup untuk membiayai kehidupannya dan kepentingan ideologinya. Sementara itu pada pihak yang lain pebisnis tidak mempunyai akses kekuasaan di satu sisi, namun memiliki modal pada sisi yang lain. Dalam kondisi seperti ini hubungan intim antara para pebisnis, politikus, birokrat, preman terus dipertahankan. MacDougall (dalam Nordholt \& Klinken, 2007) dalam penelitiannya mengenai fenomena munculnya sistem keamanan lokal pasca jatuhnya Soeharto, di Lombok, menyimpulkan bahwa kekerasan, penindasan, dan hak-hak mendefenisikan kriminalitas tidak lagi dikontrol oleh pemerintah pusat, tetapi diserahkan pada para pemimpin Lombok sendiri.

Hadiz (2010) dalam studinya mengenai basis sosial dan politik para elit di Sumatra pada pasca tumbangnya Orde Baru mengemukakan bahwa Elit-elit Orde Baru sebelumnya telah belajar untuk mendominasi demokrasi pada level lokal melalui penggunaan politik uang dan berbagai macam intimidasi dan mobilisasi politik. Sampai sejauh ini kaum reformis yang terpercaya juga telah menjadi bagian dari politik uang. Di antara elit-elit Orde Baru ini adalah birokrat-birokrat tua yang sekarang ingin mentransformasikan kedudukan mereka yang panjang dalam birokrasi ke dalam kepemilikan kekuasaan secara langsung, mereka melihat hal ini dengan bergabung dengan koalisi lokal. Diantara elit-elit politik terdapat enterpreneuer lokal yang juga memiliki ambisi yang sama. Mereka ini memperkuat posisi ekonomi mereka melalui kepemilikan kekuasaan politik langsung. Secara historis banyak dari antara mereka ini memiliki hubungan yang panjang sebelumnya dengan Golkar.

Para elit-elit lokal ini melihat desentralisasi sebagai suatu kesempatan untuk menekan klaim mereka untuk tempat-tempat yang istimewa dalam sistem post autoritarian. Mereka terlibat dengan jargon untuk melindungi agama, budaya dan identitas lokal. Dalam konteks ini tidak mengherankan kalau ada yang beranggapan bahwa hanya orang kaya yang akan memenangi politik. 
Mengikuti Hadiz (2010), Morishita (2008) mengatakan bahwa reorganisasi kekuasaan dari level nasional kepada regional telah menciptakan oligarkhi yang terpusat pada aliansi dengan para politisi, birokrat, para pebisnis. Semua ini berasal dari regim Suharto. Di beberapa porvinsi seperti di Sumatra aktor lokal berkolaborasi dengan figur-figur atau kelompok-kelompok dalam mengontrol berbagai macam aparatur yang menyimpang untuk membeli suara, mengintimidasi para pemilih dan menyerang pendukung dari kandidat yang lain selama pemilihan kepada pemerintahan lokal.

Peneliti lain juga menggambarkan gagasan shadow state untuk menjelaskan bagaimana para pebisnis local dan kepala-kepala gangster menggunakan agen-agen seperti birokrasi local, militer dan polisi pada level regional untuk mendapatkan dan melindungi kepentingan ekonomi mereka, termasuk dalam sector informal. Morishita juga menegaskan bahwa dibanyak daerah elit-elit lokal telah menggunakan etnik, agama, dan atau identitas regional sebagai ideologi dalam memperjuangkan kepentingan politik dan ekonomi mereka.

Sebuah pendapat yang lebih optimistik selain praktek-praktek kekuasaan yang koruptif sebagaimana yang dikemukakan di atas dapat ditemukan dalam pangangan Colongon, Jr \& Antlov (dalam Aspinal \& Fealy, 2003). Dikemukakan dalam penelitiannya di Majalaya, Jawa Barat melihat berbagaimacam kelompok masyarakat sipil yang muncul pasca desentralisasi seperti Citizen' Forum, z

Forum warga ini didirikan tahun 2000 oleh Organisasi Masyarakat Sipil (NGOs). Forum warga terlibat dalam isu-isu lingkungan hidup seperti polusi udara dan berbagai isu sosil lainnya. Walaupun tidak dipilih, anggota forum ini terdiri dari berbagai macam stakeholder yang berada bersama di kota seperti tukang becak, para pedangan keliling, para pekerja pabrik, usahawan, penjaga toko, para guru, pemimpin-pemimpin agama, dan lain sebagainya. Sedangkan Village Council dibentuk berdasarkan Undang-Undang No 22 tahun 1999 yang biasa disebut dengan Badan Perwakilan Desa. BPD ini dipilih setiap lima tahun oleh warga desa. BPD memiliki kekuasaan untuk membuat draf kebijakan desa, memiliki fungsi budget dan memiliki wewenang untuk mengontrol jalannya pemerintahan desa. Dan Social Movements and Mass Organisations adalah kelompokkelompok atau organisasi non pemerintah seperti serikat tani.

Sementara itu dengan optimisme yang sama Colongon melihat praktek kekuasaan desentralisasi di Bandung. Colongan mencatat bahwa Bupati Bandung memiliki jadwal mingguan untuk berdialog dengan warga pada tingkat desa dan dalam dua bulan sebelum laporan petanggungjawaban. Bupati mengundang parlemen lokal untuk memberikan feedback pada programprogram yang telah dilakukan. Lokal parlemen di distrik Indramayu misalnya mengundang 30 NGOs untuk mendiskusikan aturan daerah. Dalam konteks ini Colongon mengatakan bahwa sekarang kelompok-kelompok masyarakat sipil lebih mudah memiliki akses untuk mendapatkan dokumendokumen publik.

Colongon (dalam Aspinal \& Fealy, 2003) menulis bahwa: "One of the most significant changes has been the way in which ordinary citizens have begun to engage in dialogues, meeting and discussions on issues affecting the community. There are now many more public forums providing a means for citizens to air their grievances, settle disputes, monitor the activites of local government and demand better services."

\section{Peran Elite dalam Transisi Demokrasi pada Tingkat Lokal}

Studi mengenai eksistensi elit dalam masyarakat telah banyak dilakukan. Analisa Mills \& Pareto (dalam Seidman, 2008) tentang elit politk tidak diragukan lagi sering dikutip untuk menganalisa gejala kekuasaan elit dalam masyarakat. Tesis utama Mills adalah bahwa elit penguasa adalah mereka yang berasal dari dan berkuasa juga dalam berbagai sektor seperti korporasi, politik dan militer. 
Dalam Seidman (2008), Mills mengemukakan bahwa: “At the top of the economy, among the corporate rich, are the chief executives; at the top of the political order, the members of the political directorate; at the top of the military estabilishment, the elite of soldier-statemen clustered in and around the Joint Chief of Staff and the upper echelon... The leading men in each of the tree domains of power - the warlords, the corporation chieftans, the political directorate- tend to come together, to form the power elite of America” (p. 96). Mills kemudian memandang bahwa kekuasaan elit lebih terkait secara kuat dengan jaringan yang diikat oleh kepentingan dan ikatan personal dan struktur dari pada konflik tiga kelas (kelas atas-menengah-bawah).

Sementara itu Pareto (dalam Varma, 2001) melihat bahwa dalam setiap masyarakat tegas Pareto) selalu ada gerakan yang tak dapat ditahan dari individu-individu dan elit-elit kelas atas hingga kelas bawah dan dari tingkat bawah ke tingkat atas. Kondisi ini melahirkan apa yang disebut dengan sirkulasi elit. Sirkulasi elit dapat dipahami dalam dua konteks yakni pertama, pergantian di antara kelompok-kelompok elit yang memerintah itu sendiri dan kedua, pergantian di antara di antara elit dengan penduduk lainnya. Pergantian yang terakhir ini bisa berupa pemasukan individu-individu dari lapisan yang berbeda ke dalam kelompok-kelompok elit yang suda ada dan individu dari lapisan bahwa yang membentuk kelompok elti baru dan masuk ke dalam suatu kancah perebutan kekuasaan dengan elit yang sudah ada.

Pareto sebagai mana yang dijelaskan oleh Varma (2010) sangat pesimis dengan prilaku para elit akan mendorong demokratisasi. Bagi Pareto elit-elit tidak lain sebagai spekulator dan para rentenir. Prilaku para elit menunjukan karaketeristik yang mirip dengan cara yang dikedepankan Machiaveli dalam membentuk klik-klik pemerintahan. Terdapat dua tipe elit tegas Pareto yakni mereka yang memerintah dengan kelicikan dan yang memerintah dengan cara paksa. Di dalam usahanya untuk mengabsahkan ataupun merasionalkan penggunaan kekuasaan mereka, elit-elit ini melakukan penyerapan atau menggunakan mitosi-mitos yang mereka ciptakan untuk mengelabui massa guna memperalatnya.

Teori Pareto mengenai elit sebagaimana yang dijelaskan di atas terlalu menekankan peran elit dan tidak melihat kemungkinan individu-individu bahkan kelompok mass non-elit untuk mempengaruhi kebijakan para elit, atau sekurang-kurangnya mencegah elit untuk menghindari penyalagunaan wewenang atau kekuasaan yang dimilikinya. Dalam konteks ini Pareto berbeda dengan Manheim (dalam Varma, 2001). Mannheim membangun suatu konsepsi tentang demokrasi sebagai suatu sistem politik di mana partai-partai politik berlomba-lomba untuk mendapatkan suara massa pemilih, elitnya relatif terbuka dan direkrut atas dasar kualitas, dan massa penduduk dapat berpartisipasi dalam mengatur masyarakat setidaknya dalam hal kebebasan untuk memilih elit tandingan. Dalam konteks adanya ruang bagi munculnya partisipasi warga, pembentukan suatu kebijakan publik ada di tangan para elit, tetapi hal ini bukan berarti bahwa masyarakat tersebut tidak demokratis. Selama masih cukup bagi demokrasi di mana warga negara secara individual, meskipun dicegah untuk menjalankan peran pemerintahan secara langsung, paling tidak mempunyai kemungkinan untuk menjadikan aspirasi mereka dapat terasakan pada interval tertentu. Dalam suatu negara demokrasi yang diperintah dapat selalu bertindak untuk mengganti para pemimpin mereka atau untuk memaksanya mengambil keputusan-keputusan atas dasar kepentingan masyarakat banyak.

Sebuah pandangan yang lebih optimis menegnai prilaku para elit dapat dijumpai dalam pemikiran Dahl (dalam Varma, 2001). Dahl mengemukakan bahwa pare elit politik memiliki kecakapan untuk tanggap terhadap kepentingan warga negara biasa. Kebanyakan rakyat menurut Dahl sedikit banyaknya mempunyai pengaruh, karena para pejabat yang terpilih meletakan kehendakkehendak nyata dan imajiner para pemilihnya dalam pikirannya di dalam memutuskan kebijakankebijakan apa yang akan diambil atau ditolaknya. Lebih jauh Dahl menegaskan bahwa struktur politik, dalam palaksanaanya dapat dianalisa berdasarkan kelompok-kelompok yang sangat berpengaruh yang pada kenyataannya, mengawasi dan mengarahkan mekanisme kekuatan politik. Dahl dalam konteks ini membicarakan egalitarianisme dalam konteks kompetisi di antara kelompok-kelompok minoritas 
yang berpengaruh dan mempunyai kekuasaan untuk membuat kebijakan. Pembicaraan Dahl mengenai egalitarianisme berkaitan dengan partisipasi dalam poliarki, sub-struktur elitis dari masyarakat, dengan suatu pandangan akan mempunyai akibat pada bagian-bagian perumusan keputusan.

Model yang dikembangkan oleh Manheim dan Dahl di atas menggambarkan bahwa demokrasi telah dipahami sebagai suatu proses yang berkesinambungan di mana hak-hak politik dan kekuatan untuk mempengaruhi keputusan atas kebijakan sosial secara progresif diperluas pada kelompokkelompok penduduk yang tertindas. Dengan kata lain, demokrasi mencerminkan suatu gerakan politik dari masyarakat kelas bawah untuk menentang kekuasaan kelas-kelas kaya dan aristokrasi.

Berdasarkan uraian teoretik di atas, maka yang dimaksudkan dengan elit dalam penelitian ini tidak hanya menyangkut elit-elit politik yang berkuasa, tetapi juga elit-elit yang berada di luar arena politik yang memiliki potensi untuk mempengaruhi, menolak atau pun menerima setiap kebijakan sosial yang dibuat oleh para elit politik yang berkuasa. Ini berarti bahwa elit dalam konteks penelitian ini terdiri dari elit politik, ekonomi, budaya dan agama dan kelompok organisasi masyarakat sipil.

\section{PENUTUP}

Deskripsi singkat di atas menunjukan bahwa transisi demokrasi pada tingkat lokal tidak saja ditentukan oleh ada atau tidaknya institusi demokrasi pada tingkat lokal seperti pemilihan umum, kebebasan pers, partai politik, dan organisasi masyarakat sipil. Berdasarkan penelitian yang dilakukan oleh para peneliti di atas, maka jelas bahwa transisi demokrasi pada tingkat lokal sangat ditentukan juga oleh basis sosial dan praktek kekuasaan yang dilakukan oleh para elit politik lokal. Praktekpraktek kekuasaan yang koruptif, penuh dengan intimidasi, kekerasan dan cenderung oligarkis sebagaimana yang terjadi pada masa Orde Baru mencerminkan proses kaderisasi baik pada tingkat partai, maupun masyarakat sipil belum berjalan dengan baik. Tidak berjalannya proses kaderisasi ini menguntungkan para elit yang sejak Orde Baru memang sudah kuat. Para elit ini menjadi para pemimpin partai, menguasai bisnis dan bahkan mengontrol masyarakat sipil. Dalam kondisi seperti ini, maka tidak heran kalau orang beranggapan bahwa desentralisasi tidak hanya peralihan kekuasaan dari pusat ke daerah, tetapi juga memperkuat para elit politik lokal yang secara historis memang sudah kuat.

\section{DAFTAR PUSTAKA}

Aspinall, E., \& Fealy, G. (2003). Local power and politics in Indonesia. Singapore: Institute of Southeast Asian Studies.

Bardham, P. (2002). Decentralization of governance and development. Journal of Economic Perspective, Volume 16, number 4-Fal.

Braun, J. V., \& Grote, U. (2002), Does Decentralization Serve the Poor ?”, in Ethisham A., \& Tanzi, V. (eds), Managing Fiscal Decentralization, London: Routledge.

Darmawan, D. R. E. (2008). The practice of decentralization in Indonesia and its implications on local competitiveness. Public Administration-Public Governance Study, School of Management and Government, University of Twente, Enschede, The Negerlands.

Hadiz, R. V. (2010). Localizing power in post-authoritarian Indonesia: A Southeast Asia perspective. California: Stanford University Press. 
Katorobo, J. (2005). Decentralization and local autonomy for participatory democracy. Global Forum on Reinventing Government towards Participatory and Transparency, 24-27 May, 2005, Seoul, Republic of Korea.

Morishita, A. (2008). Contesting power in Indonesia's resource-rich regions in the era of decentralization: New strategy for central control over the regions. Academic Research Library.

Nordholt, H. S., \& Klinken, G. V. (ed.). (2007). Politik lokal di Indonesia. Jakarta: Yayasan Obor dan KITLV-Jakarta.

Ribot, J. C. (2007). Representation, citizenship and the public domain in democratic decentralization. Development.

Seidman, S. (2008). Contested knowledge: Social theory today. Singapore: Blackwell Publishing.

Van Berkel, R. (2006). The decentralization of social assistance in The Netherlands. The International Journal of Sociology and Social Policy.

Varma, S. P. (2001). Teori Politik Modern. Jakarta: Raja Grafindo Persada. 